\title{
Delocalization and Spatialization of the Classroom: Deterritorialization in Education
}

\author{
Dante Augusto Couto Barone, Milton Antonio Zaro, Cláudio de Musacchio* \\ Universidade Federal do Rio Grande do Sul, Brazil \\ *Corresponding author: claudiodemusacchio@gmail.com
}

\begin{abstract}
This study aimed to discuss the concepts of the deterritorialization of the teacher and student roles in education. Among the concepts discussed, two are relevant for the considerations: the delocalization and spatialization of the classroom. As the environment for research, teachers and primary school students from public schools in Porto Alegre and surroundings were used. The guiding issue for the research was on how students and teachers were solving the problems caused by social pressures exerted at school for the use of mobile phones, tablets and social networks in the classroom. Initial results indicate significant progress for the introduction of new aspects and characteristics in the TEACHER and STUDENT territories, and one of the conclusions is that both the delocalization and spatialization are concepts that should guide teacher training courses more significantly in order to improve practices and education in the teaching and learning relationship. In conclusion, the educational use of social networking in education, and audio and video media in the production of educational content built by the students themselves, nurture new spatialization and delocalization, providing results and students who are more reflective and protagonists of their cognitive and intellectual growth.
\end{abstract}

Keywords: interdisciplinarity, social networking in education, interdisciplinary educational practices, deterritorialization in education

Cite This Article: Dante Augusto Couto Barone, Milton Antonio Zaro, and Cláudio de Musacchio, "Delocalization and Spatialization of the Classroom: Deterritorialization in Education." American Journal of Educational Research, vol. 3, no. 11 (2015): 1417-1428. doi: 10.12691/education-3-11-11.

\section{Introduction}

The main purpose of this article is to discuss and present research findings and how the guidelines of communication and information are seen by traditional education and how the phenomena of Delocalization and Spatialization can be perceived in contexts from the introduction of the deterritorialization of the TEACHER and STUDENT actors, bringing a new set of lens for viewing the phenomenon that swells in society and receives refreshed contours with the introduction of contexts and realities of the virtual world in the subjectivity of addressing issues of school teaching and learning.

In the educational environment, communication and education are "holding hands" through dialogic activities within inter and transdisciplinary contexts in an intertwined web of relationships and meanings. Expanding the concept beyond the transmission of content and considering the perspective of possible behavioral changes in the teaching and learning relationship, the aim with this research is to study the communication and education terms in instances of the Teacher, Student, and Teaching territories, and as such, observe some variables in the possibilities of existing relationships in the educational universe.
Initially, it is necessary to contextualize the concepts of deterritorialization in education and the delocalization and spatialization of the classroom in order to demonstrate the phenomena observed in field research and bring the progress made with such educational methodology under the light of science.

Considering also, that there are numerous other studies of traditional teaching and learning centers, and considering that the contemporary student is different from past generations, we sought to discuss how this new methodological proposal with the aid of new technologies, can develop quite unique solutions to improve the reflection, construction of meaning and what really matters for youth to know during school years.

In order to verify this deterritorialization in education, a school survey was conducted involving teachers and students from various educational institutions, and various educational levels. The survey used interdisciplinary methodological resources and concepts and contemporary technologies of social use to study the behavior of students facing the challenges of research, reflection and producing educational content. To conduct the survey some indicators were created to measure the stages of analysis and observation of the experiment. The concepts, information and research methodology are presented below, as well as the confirmed results and previous analyzes aiming to assist educators and researchers toward understanding the methodological and technological 
processes that surround the educational environment in primary and secondary school.

\section{Concept of Deterritorialization in Education}

In the dictionary, Deterritorialization is, by definition, a loss of territory. In a more cartographic proposal on the subject, a more comprehensive, holistic and systemic observation perspective about the definition is sought. According Ianni $[15,16,17]$ "... The subject of knowledge does not stay in one place, letting its gaze float through many places, near and remote, in present and past tenses, real and imagined." If territory gives the idea of stability and organization, the action of deterritorializing is to promote disorder, reflection, review, fragmenting its principles and dogmas and rebuilding, defragmenting again, but with new shades, aspects and characteristics.

So, the use of the term occurred for the first time during field research on Interdisciplinarity, social networking in education and audio and video media, indicating that the values and norms of the social contract built between the TEACHER and STUDENT territories should be rethought and reassessed by proposing new possibilities and fields.

Imagining, according to Guattari and Rolnik [14], that territory is synonymous with ownership, of closed subjectivity itself, and by being a set of representations that follows on a series of stereotypical, dogmatic behaviors perpetuated for centuries, what is proposed is the discussion of this location and existing pragmatic spatialization between the TEACHER and the STUDENT and between TEACHING and LEARNING.

The term borrowed from Deleuze's analysis [8] in the field of Geography, may well be used to promote new spaces for discussion and studies in Education, Pedagogy and Cognitive Psychology, in an interdisciplinary area model that is born with the original proposal of Neuroeducation.

But as there is no territory without a vector output, the proposal of deterritorializing education suggests that there is reterritorializing another point of analysis of educational methodologies. If new roles are possible in the Teacher and Student territories, as observed in the survey conducted, the possibility of new variables being incorporated into the proposed model and thus promoting a new set of lenses for the observation of behaviors is also possible.

\section{Concept of Delocalization and Spatialization of the Classroom:}

The concepts of LOCALIZATION and SPACE, assigned in the school setting and considered as instances of the Teacher and Student territories. The Pedagogical territory shall not be considered in this discussion, although its importance is vital to carry out the management of educational and learning projects.

The communication between the Teacher and the Student is still considered as a relationship of power and, as such, whoever wants to explore loses the power, considering that the information is not alone in the different school locations and spaces. It is accompanied by the power with which teachers imposed it, whether embedded or not, in ideological or socio-historical projects.

In the overall concept of communication and education, the transmission of content and/or information which is then worked internally on students is considered as fundamental, causing the learning event, when understood, of course. Thus, communication and education produce, on one side the transmission, and on the other, the reception.

This way, to communicate and educate is quintessential to the action of producing an information transfer from one pole to the other, and on one side there is a subject characterized as the issuer / educator, and on the other, a subject named receiver / student. And anything that interferes or impedes the arrival of the content or information on the receiver, we consider as noise that can hinder the understanding of the information transmitted by the receiver. Thus, the concept of LOCALIZATION means the place where there are transmissions of content and information. This place can be a classroom, library, laboratories, sport courts, etc.

In Geography, Cresswell [7] in his book "Place: a short introduction," cites the political geographer Agnew [1], who cites, in a classical and didactic way, three fundamental aspects to the understanding of place: location, locale and sense of place.

Location represents the fixed and objective coordinates of a point on Earth. The word place is often used as a sense of location. But as Cresswell [7] explains, places are not always fixed, only its coordinates. For example, a ship on high seas, is currently somewhere, even if this location is constantly changing. When traveling by car through a small town, you can mention that you are somewhere and then a moment later, somewhere else.

Now, the concept of locale refers to things, objects. For example in a city, the location is comprised within the material extension about the references used.

Human settlements, in large cities, live in buildings, houses, roam through streets, avenues, in and out of office buildings, shopping malls, public and private buildings. The sense of place is understood as a subjective concept. Paintings, films, books, conversations, songs and others rely on the capacity for reflection about places that have meaning. The sense of place is linked to the emotions that people have as the location.

Another commonly used concept of place is the association, which Cresswell [7] describes, of places that may even no longer exist, except in our minds and memories. It is on this concept of subjective place that the reflection of this research is worked on. DELOCALIZATION, used in this context, is attributed to the change in positioning in regards to opinion, argument or expression on what a place was like, but is no more due to a physical change of transposition and subjective sense.

For example, changing a place that existed in our past and that no longer exists. However the place is now used in another way and in another context. In the past, the existing places for film screenings (cinema) were big houses with hundreds of seats, and located in different neighborhoods of cities around the world. Today, the action was delocalized to another scenario and placed in 
places like shopping malls. The study of DELOCALIZATION in education therefore has the sense to link subjectively, how the educational scenario in traditional education once was and how it is being proposed by the new methods of teaching and learning.

Thus, the Delocalization and Spatialization of the Classroom is a demonstration of how these new scenarios can improve teaching practices, making them more interdisciplinary, and how the social network environment can be inserted into the school to bring students and adolescents back to the motivation of wanting to study, learn, interact and collaborate with each other. There are also the innovative aspects of exposure to tasks of building the content themselves, through audio and video, providing new relations in the construction of subjectivity itself, as the subjects they are, and in the way they see themselves in the production of school content.

\section{Methodological Proposal in Network - Sound Rhizome}

According to Deleuze and Guattari [9], the construction of thoughts in these places occurs through the rhizome model. Rhizome is a proposal for construction of thought, where the concepts are not hierarchical and there is no center, originating from different points, such as a network of relationships, according to the studies of Barabási [2]. That is, in these subjective school places, spatialization and delocalization take place from different concurrent points.

To describe the subjectivity of educational spaces between the TEACHER and the STUDENT, as distinct territories, we must first observe the main characteristic in the definition of space, called sound. Sound is a characteristic that is spread across multiple physical environments: in water, air, wood, metal; except in vacuum, because there is no sound without oxygen. The existing movement in the educational ecological space is observed by the spreading of the characteristic sound of children talking, playing, laughing, dancing, singing, etc.

In addition to this characteristic of space, human voice should be noted as a kind of sound that reaches all humans and is recognized according to its individual signature, called timbre. Just as in nature, natural sounds caused by winds, tides, birds singing and audible noise emitted by humans and their inventions, make up much of what we call sound ecology.

Within this analyzed spectrum, which is educational places, the characteristic sounds of the school are determined by the actors, teachers and students, servants, assistants, coordinators and direction of the institution. All of these human sounds together represent the universe we want to analyze as possible spaces of subjectivity, which occur in the TEACHER and STUDENT territories.

Therefore, the concept of educational spaces is represented by the types of sounds that we can capture and characterize the physical environment in which they are built. Some examples of spaces can be nominated: the classroom space has characteristic sounds of students and teachers in teaching and learning moments. In a traditional school, the sounds are predominantly teachers, who choose schemes and teaching techniques potentially favoring lecture. The proposed methodology will delocalize and spatialize in a way as to subvert this didactic choice.

Another space that is characterized by the sound it produces is the physical education environment where children are commonly making lots of noise by being in stress periods, playing games. These are generally regarded as playful moments of intense interaction and collaboration, important and vital to build the SOCIAL $\mathrm{ME}$, also known as E-Social. The physical space called the gymnasium or multipurpose area for presenting possibilities for many types of sports interaction, has a typical acoustic resonance of sounds that propagate in the air. Another characteristic sound of this place is the sound produced by the rubber shoes that screech while sliding through smooth and slippery terrain, typical of these environments.

In the description of sound ecology in educational environments, numerous other spaces characterize the environment by the lines that these environments reproduce. During recess or break time, where children run, play, talk, eat and play, the sound produced is very characteristic and can be observed clearly by being an area with very clear definitions of the type of existing interaction and communication.

Another characteristic space recognized by the sound it emanates, or the sound it does not emanate, is the school library. A place where, until recently, it was forbidden to speak loudly; a place to privilege reading and the reflection of reading, but with low probability of interaction, communication and collaboration among students. Students and teachers meet at the library, usually to carry out research in books and journals. But still, the sound ecology produced in this environment is a very low hum, barely audible and difficult to implement projects for new subjective constructions.

Thus, it is observed that the sound ecology produced by the various subjective school spaces characterizes the type of interaction, communication, collaboration, teaching and learning you want to produce in certain places. Therefore, the spatialization of these school environments is closely linked to the type of relationship established between people. In a way, it can be said that such spaces have certain sounds and are confined in the practice for each type of environment. We will not hear sounds from one environment in another environment, and so on. The nature of each sound is associated with that environment that originates it, and therefore, each environment produces its own distinctive sound and its expected learning.

\section{Media-education - A Necessary Technological Deterritorialization}

The impact caused by the communication media and the generation of radio and television information, and more specifically, the Internet, becomes, according to Mitchell [21], Castells [6], Meditsch [19,20], crucial to urban and collective life, to the same degree of importance as transport systems. Computers, the Internet and Social Networks brought another dimension represented by a set of services and technologies based on location and spatialization. 
The media of communication and information has been the focus of studies, treaties and theses of many thinkers, scholars and authors of numerous publications. $[4,5,10,18,22,23,25]$.

In addition to the important aspects of the studies of how the media has affected the behavior of children and adolescents, Teruya [26], illustrates saying that in addition to the importance of these media being included in school curriculum is the profusion of types and utilities with which these media are being handled in schools, although there are yet to be significant scientific studies as to its benefits or harms, there is a profusion of possibilities of how these media cannot represent educational purposes, formatting numerous conditions to combine what is wanted for youth to study, learn and relate to in the school environment.

Although studies of media have been discussed by a growing number of scholars and researchers, there is still much to study as to its effects and symptoms, so we can clearly tell how relevant it is to teach and learn with the help of media.

According to Bevort \& Belloni [4], media education is the essential element of socialization processes of the younger generations, at the same time it gives opportunity to the older generations, at the same degree of importance. The biggest challenge seems to be to incorporate media to teaching practices, much more than to teach young people how to use it. The overall concept is to educate for and about media, with media and through media. The concepts of the use of media in education differ in the ownership of media and its different meanings, depending on the angle from which we are analyzing.
The natural order is to first teach the students to use media, their commands, routines and resources, then to start teaching school subjects with the support of media, and in the next step, teach through media. Finally, we teach for media, i.e. media begins to enjoy the privilege of being able to be relevant and important in the transport of information, as a contribution that states that without media we cannot communicate at the speed and adequacy they suggest.

EDUCATING ABOUT MEDIA - The first step of the teacher is to educate his/her students for the use of media, comprising the universe of its commands, operating buttons and specific functions in order to explain, for example, school subjects to teach the operation of PowerPoint, the projector, the 3D printer, the interactive whiteboard, etc.

EDUCATING WITH MEDIA - On the next step technology is already being used to assist teachers in teaching and in the technique of activities, for example, in the use of cell phones in the classroom by using educational applications.

EDUCATING THROUGH MEDIA - Corresponds to the production of audio and video by students in the classroom, related to school subjects. When the students themselves produce such educational materials, there is a substantial improvement both in motivation and in reflection, given that they need to memorize, internalize and discuss the contents researched.

EDUCATING FOR MEDIA - Means when teachers teach students how an educational radio program or an educational television news program should be

\section{DELOCALIZATION \\ AND SPATIALIZATION}

IN THE CLASSROOM

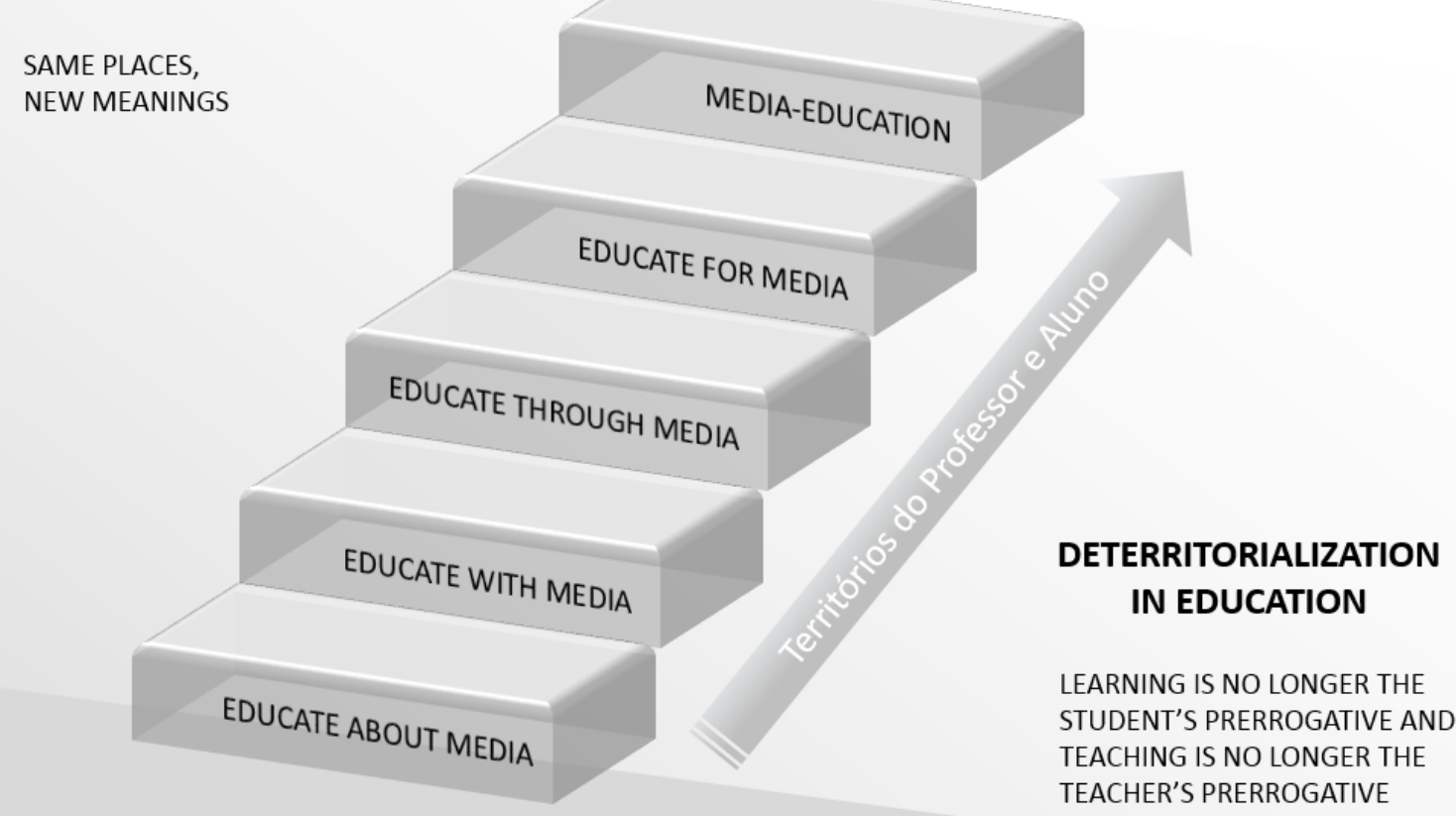


Media-education focuses on two important factors: observation and analysis. The observation factor can be noticed when students watch their productions of audio and video to reflect on the contents and their performances in its production. The analysis is observed when students reflect on what they did, reconfigure, repair and remake not only the content but the scripts and performances of each, reproducing an extensive work of reorganizing the internalization of the concepts learned, in case there were any errors in finding the information searched.

In addition to the benefit of media-education, the pedagogical use of social networking in education also has to be considered, specifically in the classroom as an important instrument of socialization, communication, interaction and collaboration. According to Deleuze and Guatari [9], the analogy of the rhizome model compared to a tree, may be very well applied in this case, imagining that all actors, teachers and students, are WE, interwoven in a web of relationships, establishing that there is no longer a single point of convergence for the search for information or for the arrival to results of educational research. Teachers are now able to feel more as participants and learners than as teachers, at the same time that students can perform activities more as instructors than merely learners. This shift in the different aspects and characteristics of the territorial roles of TEACHER and STUDENT is what we call DETERRITORIALIZATION IN EDUCATION.

In this perspective, it is important to consider that the current educational topology in the physical classrooms, which still presents the teacher as the protagonist of the teaching and learning relationship, does not contribute or does little to assist in the search of these new possible interactions between the actors involved. If in the virtual environment, provided by social networks, all of WE are relevant to the exchanges and interactions on the physical environment, the classrooms cannot evolve into other systems of teaching and learning. It is therefore necessary to examine another possible learning cycle involving students in the direct production of content, using the existing contemporary technological possibilities with the assistance of interdisciplinary methodologies.

\section{OBSERVATION}

\section{CYCLICAL MOVEMENT OF LEARNING}

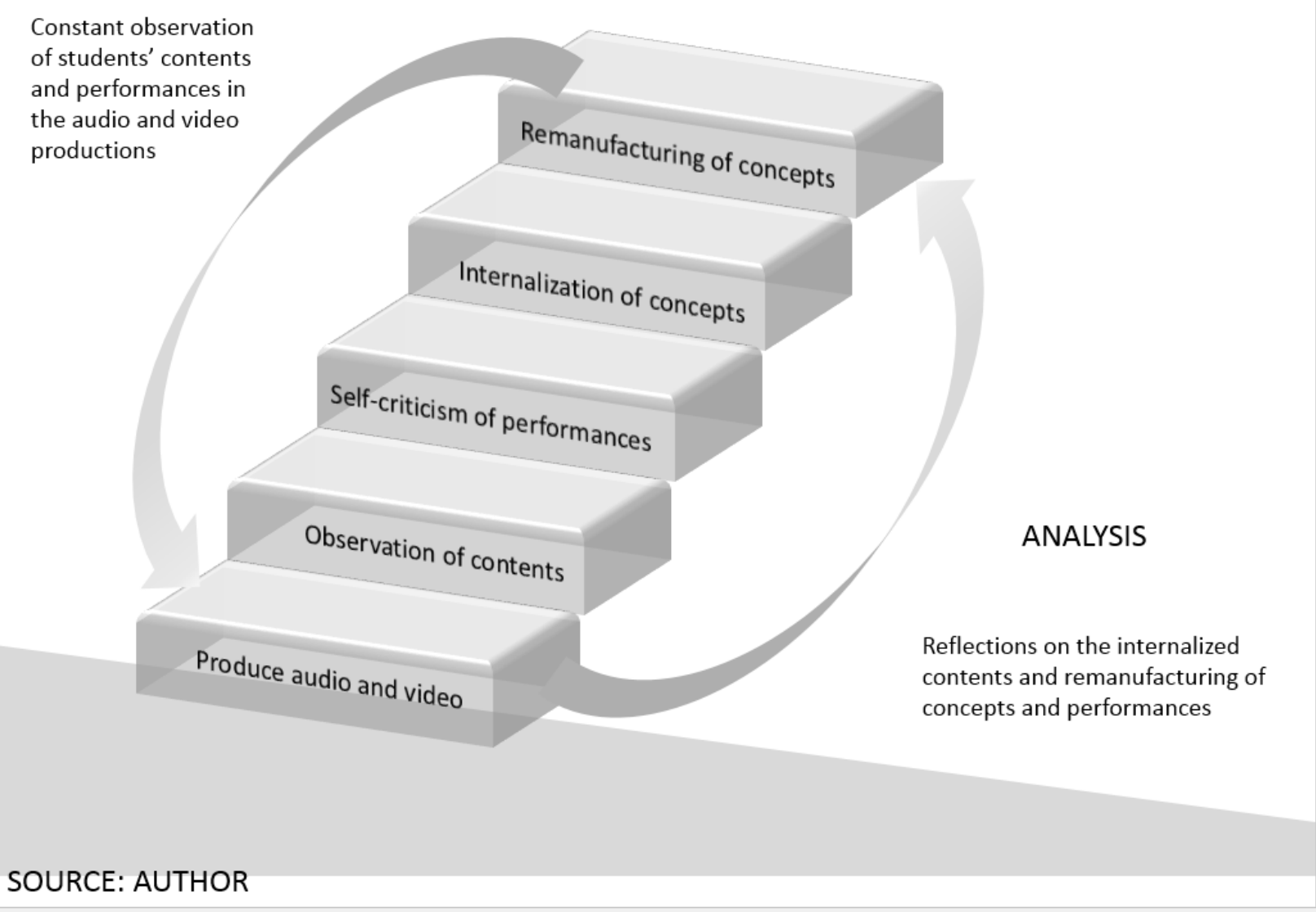

Figure 2. Cyclical movement of learning in the proposed methodology (SOURCE: Author)

As noted in the figure above, students produce research, organize information, create the scripts for recording (storyboards) and record the audio and video media.

After recording, they observe the contents, verify them and make self-criticism of the performances (actors on stage), internalize the concepts, i.e. memorize what is important and relevant to learn, and finally, study what was correct and what was incorrect in the analysis of the activity, promoting remanufacturing of the contents, resulting in another recording of audio or video and the process is repeated until the content is satisfactorily acceptable to the creating group, and that their performances are equally acceptable to their own criteria of quality, aesthetics, presentation, sound, etc.

This cyclical movement of production occurs due to the use of media, which would not happen in the traditional model of teaching and learning, as there would be no scenario to analyze, except for the assessment (tests). 


\section{The History of Media in Different Countries}

According to Fantin [11], media-education was placed in education in different ways and had more or less impact according to the cultures. Here are some examples of the integration of media and its impacts, respecting and taking into account the specificities of each country:

In Canada, since 1987, the use of media in the classroom is mandatory. And so the process begins, through the subjects of Arts and English Language, being one of the first countries to deploy media for students from 12 to 13 years old.

In England, the use of media began around the 60s, but only in 1988, with the Education Reform Law passed upon suggestion of the British Film Institute, it would be provided in the school curriculum that the subject of media-education was to be an item in the teachers' training in multi-disciplinary curricular character.

The Nordic countries also adopted media education in its education system. In Finland, it was adopted in primary schools in the 70s and in secondary school since 1977, integrated with other subjects. In Sweden, media education is compulsory in schools since 1980, linked mainly to the subjects of Arts, Civics and History.

In Norway, films began to be used in the 30s, and were included in the curriculum in 1974, but only in 1985 was Education made principal in schools and in teacher training courses, becoming mandatory in curriculum guidelines of primary and secondary schools.

In Denmark, Media-Education gained momentum from the 80s, being linked to the Danish teaching discipline. In Italy, it exists since the 40s and has strong influence of cinema and its use as a tool in the process of teaching and learning, providing a cinematic culture and inserting media education in the school curriculum [11].

\subsection{Reality of Media in Brazil}

In Brazil, the experience with media-education occurred in a unique way, different from the European experience. Although very early in the use of mediaeducation, even due to the advancements promoted by the implementation of the New Curriculum Standards, this issue was included in the multi-disciplinary themes, in the proposal of languages and technologies.

Although there is a subject of media-education in schools and, therefore, there is an application of mediaeducation as a construction of representations in different subjects, there is a rather high number of applications as the universe of presentation of content, of which movies and documentaries are the best examples to name.

The survey conducted by Comitê Gestor de Internet no Brasil (Internet Management Committee in Brazil), regarding the use of information and communication technologies in Brazilian schools between August and November 2010, involving students, teachers, coordinators and principals of public state and municipal schools in the metropolitan areas that offered primary and secondary education, pointed out some important results about the availability of equipment and its pedagogical use for the production of content.

According to a sample of 500 schools from the school census of 2007, there were 7453 persons interviewed composed of 1541 teachers, 4987 students, 497 principals and 428 coordinators. The results presented were as follows:

Table 1. Comitê Gestor de Internet no Brasil - 2010

\begin{tabular}{|l|c|}
\hline \multicolumn{2}{|c|}{ Table 1. Comitê Gestor de Internet no Brasil - 2010 } \\
\hline TV & AMOUNT \\
\hline PRINTER & $99 \%$ \\
\hline VCR / DVD & $99 \%$ \\
\hline RADIO & $96 \%$ \\
\hline OVERHEAD PROJECTOR & $83 \%$ \\
\hline TELEPHONE & $83 \%$ \\
\hline MIMEOGRAPH & $81 \%$ \\
\hline DIGITAL CAMERA & $81 \%$ \\
\hline DATASHOW PROJECTOR & $78 \%$ \\
\hline CD PLAYER & $75 \%$ \\
\hline SATELLITE DISH & $69 \%$ \\
\hline CAMCORDER & $54 \%$ \\
\hline CELL PHONE & $42 \%$ \\
\hline SOUIC: AGhOr & $8 \%$ \\
\hline
\end{tabular}

Source: Author.

Also, survey data shows that educational institutions had an average of 23 computers, and in the Southern Region, this number rose to 27 . The highest rates are in secondary schools, with 27 units. In primary school II with 23 and in primary school with only 20 .

However, 64\% of teachers said that students know more than the teachers regarding the handling of computers and the Internet. An interesting finding is that $80 \%$ of the teachers surveyed claim they know the uses of technology in teaching and learning activities and how to use computers and the Internet at school.

\subsection{Studies of the Importance of Media- Education}

There are several studies that affirm the importance of educating through media in order to reduce the damage caused by the harmful influences of its non-approach, leading to training needs for the students in the professional market.

For Guareschi [13], media is "the heart of the information society", being responsible for the new capitalist system development model in current times. Whoever has the skills and abilities to use it, has increased placement conditions in a market which is in constant transformation.

For Silverstone [25], media should be studied in the social, cultural, political and economic dimensions since the world is wrapped in a curtain of media coverage. Silverstone adds that "We need to understand how it contributes to the exercise of power in society, both inside and outside the established political process".

Morin [22], citing T.S. Eliot, complements saying that knowledge is only knowledge as an organization if it is related to information and inserted into its contexts.

Information is one of the aspects of the content processed by individuals in their relationship with the environment and the development of intelligence is the adaptive form of man in nature and depends on the quality of the interaction. But when the image wears human clothes, then it translates into a new territory of 
subjectivity, having to reconstruct the meaning that the information brings together from this body, created as a body image.

But what is the importance of this body image in times of so much visual, graphic, and film technology? Part of this answer is demonstrated in the results of the following field research.

\subsection{Field Research}

For the field research on deterritorialization, delocalization, spatialization, interdisciplinarity, educational use of social networks and the use of audio and video media in the classroom, five distinct groups were considered. The study took place in the first half of 2015 and sought to investigate, among other variables, if interdisciplinary methodology could be applied in different contexts with existing technological support.

The groups studied were:

Table 2. Groups surveyed and analyzed from March to June 2015

\begin{tabular}{|c|c|c|c|}
\hline STUDY GROUPS & EDUCATIONAL INSTITUTIONS & NUMBER OF STUDENTS & NUMBER OF TEACHERS \\
\hline $\begin{array}{c}\text { PRIMARY SCHOOL } \\
\text { GROUP A }\end{array}$ & 2 & 86 & 2 \\
\hline $\begin{array}{c}\text { SECONDARY SCHOOL } \\
\text { GROUP B and C }\end{array}$ & 2 & 210 & 2 \\
\hline $\begin{array}{c}\text { UNDERGRADUATE } \\
\text { STUDIESGROUP D }\end{array}$ & 1 & 80 & 1 \\
\hline $\begin{array}{c}\text { TECHNICAL LEVEL } \\
\text { PROGRAMSGROUP E }\end{array}$ & 1 & 22 & 4 \\
\hline TOTAL & $\mathbf{6}$ & $\mathbf{3 9 8}$ & $\mathbf{9}$ \\
\hline
\end{tabular}

SOURCE: Author.

Table 3. Assumptions and results - aspects and features

The indicators studied and the quantitative figures from the survey:

\begin{tabular}{|c|c|}
\hline FIELD RESEARCH IN NUMBERS & TOTAL \\
\hline $\begin{array}{l}\text { 1. Interdisciplinary meetings (two or more teachers in the classroom) } \\
15 \text { interdisciplinary meetings in the groups studied }\end{array}$ & 15 \\
\hline $\begin{array}{l}\text { 2. Use of FACEBOOK in the classroom (Study Groups) } \\
6 \text { FACEBOOK Study Groups for each study group }\end{array}$ & 6 \\
\hline 3. Use of Audio and Video media in the classroom & 398 \\
\hline 4. Students set in groups in the classroom & 97 \\
\hline 5. Suggestion for the production of content by the students themselves & 100 \\
\hline 6. Scientific and school researches held in the classroom & 94 \\
\hline $\begin{array}{l}\text { 7. Use of the FACEBOOK environment by teachers and students } \\
\qquad 407 \text { student and teacher profile accounts }\end{array}$ & 407 \\
\hline 8. Creation of FACEBOOK STUDY GROUPS & 17 \\
\hline 9. Periodic posts on FACEBOOK of group activities & 421 \\
\hline 10. Likes and Shares by students to their personal profiles & 1819 \\
\hline $\begin{array}{l}\text { 11. Interdisciplinarity with teachers from other areas of knowledge } \\
124 \text { interviews with teachers and area experts }\end{array}$ & 124 \\
\hline 12. $360^{\circ}$ assessment of students (everyone evaluates all posts) & 12 \\
\hline $\begin{array}{l}\text { 13. Learning of audio and video editors } \\
\qquad \text { Format factory and Movie Maker - } 512 \text { productions of intermediate and final videos }\end{array}$ & 512 \\
\hline $\begin{array}{l}\text { 14. Use of Movie Maker for editing of videos by students } \\
185 \text { videos with credits - about the surveyed subjects }\end{array}$ & 185 \\
\hline $\begin{array}{l}\text { 15. Production of scientific articles and publishing of activities by teachers } \\
\qquad 8 \text { scientific articles published in specialized magazines and newspapers }\end{array}$ & 8 \\
\hline $\begin{array}{l}\text { 16. Technical specifications of the activities performed by invited institutions } \\
4 \text { technical notebooks on the activities }\end{array}$ & 4 \\
\hline $\begin{array}{l}\text { 17. Vocational Training and Qualification for Teachers } \\
\text { WEB RADIO IN EDUCATION and FACEBOOK IN THE CLASSROOM }\end{array}$ & 2 \\
\hline
\end{tabular}

SOURCE: Author.

Initially, teacher training was carried out with the WEB RADIO IN EDUCATION and FACEBOOK IN EDUCATION courses, giving rise to the application of the concepts necessary so that the research could be performed.

\subsection{Group Activities during Research}

The activities took place from October 2014 to June 2015. All meetings were recorded and posted on YOUTUBE. Researches are contained in the research reports and technical notebooks. The audio and video productions are published in THE STUDY GROUP on FACEBOOK and YOUTUBE.

The activities proposed to the research groups were: 
Table 4. Activities proposed to the groups surveyed

\begin{tabular}{|c|c|c|c|c|c|c|}
\hline ACTIVITIES & GROUP A & GROUP B & GROUP C & GROUP D & GROUP E & TOTAL \\
\hline INTERDISCIPLINARY MEETINGS & 3 & 3 & 3 & 3 & 3 & $\mathbf{1 5}$ \\
\hline SCIENTIFIC AND SCHOOL RESEARCH & 31 & 18 & 27 & 12 & 6 & $\mathbf{9 4}$ \\
\hline AUDIO AND VIDEO PRODUCTION & 40 & 19 & 17 & 18 & 6 & $\mathbf{1 0 0}$ \\
\hline POSTS ON FACEBOOK & 172 & 114 & 87 & 32 & 16 & $\mathbf{4 2 1}$ \\
\hline
\end{tabular}

\section{SOURCE: Author.}

Interdisciplinary meetings: Interdisciplinary meetings involving two or more teachers in the classroom to present the contents of the subject. These meetings allowed to show teachers and students participating in the research, the use of postures and pedagogical practices aimed at the methodology of interdisciplinarity in the classroom with the active participation of students.

Scientific and school research: Scientific and school researches were held in the participating groups, with students grouped into four or more participants in each group. The themes chosen were those of the subject itself. The technologies used were researches in search engines on the Internet, books in the library and interviews with teachers of the areas of the subjects researched.

Audio and video: after gathering the information of the chosen subjects, students produced audios and videos about the reflections produced in relation to the documents raised. The audios were used for the interviews and the videos for the production of research. The presentation was conceived, from the script (storyboard), by the groups themselves. The videos had different textual, theatrical and musical, content presented in the formats of television news, dramatization, parodies, in the form of conversation between the elements of the groups and testimonials from students regarding the subject researched.

Posts: After the production of audio and video, students posted in the FACEBOOK STUDY GROUP environments. Each teacher received a resource from the FACEBOOK study group to serve as communication, interaction and collaboration among students during the research.

\section{Facebook Study Group Web Addresses}

FACEBOOK study groups contributed to the communication of students and teachers during the survey as well, with the interactions and collaborations of student groups.

Table 5. Links to FACEBOOK study groups used in the research

\begin{tabular}{|c|c|c|}
\hline STUDY GROUPS & LINK & PARTIC \\
\hline DESERTIFICATION & https://www.facebook.com/groups/musadesertos/ & 11 \\
\hline ELECTRICITY & https://www.facebook.com/groups/musaluzeletricidade/ & 11 \\
\hline OXYGEN & https://www.facebook.com/groups/musaoxigenio/ & 11 \\
\hline FRACTIONS & https://www.facebook.com/groups/musafracoes/ & 11 \\
\hline FOOD & https://www.facebook.com/groups/musaalimentos/ & 11 \\
\hline LANGUAGES & https://www.facebook.com/groups/musaidiomas/ & 11 \\
\hline BODY MOVEMENT & https://www.facebook.com/groups/musamovimentodocorpo/ & 11 \\
\hline PARODY & https://www.facebook.com/groups/parodias.pgie/ & 35 \\
\hline SERVICE MANAGEMENT & https://www.facebook.com/groups/gestao.servicos.cnec/ & 29 \\
\hline STRATEGIC PLANNING & https://www.facebook.com/groups/planejamento.estrategico.ne/ & 48 \\
\hline PORTUGUESE LANGUAGE AND LITERATURE & https://www.facebook.com/groups/lingua.portuguesa.literaratura/ & 82 \\
\hline HISTORY & https://www.facebook.com/groups/historia.pesquisa.ufrgs/ & 34 \\
\hline BIOLOGY & https://www.facebook.com/groups/ciencias.pesquisa.ufrgs/ & 39 \\
\hline TECHNICAL SCHOOL & https://www.facebook.com/groups/eeta.interdisciplinar/ & 12 \\
\hline SENIOR CITIZENS & https://www.facebook.com/groups/terceiraidade.sjt/ & 35 \\
\hline EDUCATIONAL RESEARCHES & https://www.facebook.com/groups/pesquisas.escolares/ & 4023 \\
\hline WEB RADIO IN EDUCATION & https://www.facebook.com/groups/webradio.na.educacao/ & 4347 \\
\hline
\end{tabular}

SOURCE: Author.

Comments: School surveys and Web Radio in Education are two groups that were attended by teachers and students invited from different institutions of primary, secondary and higher education, throughout Brazil. 
Table 6. Deterritorialization in education

\begin{tabular}{|c|c|c|}
\hline \multicolumn{3}{|c|}{ INDICATORS OF DETERRITORIALIZATION IN EDUCATION } \\
\hline MAIN CHARACTERISTICS & METHODOLOGY USED & TECHNOLOGY USED \\
\hline $\begin{array}{c}\text { SCIENTIFIC } \\
\text { AND SCHOOL } \\
\text { RESEARCHES }\end{array}$ & World understanding through experimentation & $\begin{array}{c}\text { Research in search engines and ABNT writing } \\
\text { of technical texts }\end{array}$ \\
\hline $\begin{array}{l}\text { ACTIVITIES } \\
\text { ACTIVITIES }\end{array}$ & $\begin{array}{l}\text { Working in communication, interaction and } \\
\text { collaboration }\end{array}$ & Use of synchronous communication systems \\
\hline $\begin{array}{c}\text { STAGES } \\
\text { OF RESEARCH }\end{array}$ & Encouraging collaborative reflection & Use of FACEBOOK and HANGOUT \\
\hline $\begin{array}{l}\text { CONSTRUCTION OF } \\
\text { DOCUMENTS }\end{array}$ & $\begin{array}{c}\begin{array}{c}\text { Production of school subjects by the students } \\
\text { themselves }\end{array} \\
\end{array}$ & Building documents collaboratively \\
\hline $\begin{array}{c}\text { PLAN } \\
\text { OF CONTENT }\end{array}$ & Construction of audio and video storyboards & $\begin{array}{l}\text { FORMAT FACTORY AND MOVIE MAKER } \\
\text { Software }\end{array}$ \\
\hline $\begin{array}{l}\text { AUDIO AND VIDEO MEDIA IN THE } \\
\text { CONSTRUCTION OF CONTENT }\end{array}$ & $\begin{array}{l}\text { Multisemiotic content: reading, writing, pictures, } \\
\text { photos, audio and video }\end{array}$ & $\begin{array}{l}\text { FACEBOOK environment and other social } \\
\text { networks }\end{array}$ \\
\hline $\begin{array}{c}\text { REFLECTIONS } \\
\text { OF CONTENT }\end{array}$ & Interpretation of texts and production of dialogues & Audio and Video of interviews and dialogues \\
\hline $\begin{array}{c}\text { INDIVIDUAL } \\
\text { PARTICIPATIONS }\end{array}$ & Everyone is seen and heard by everyone & Recording of individual participations \\
\hline $\begin{array}{l}\text { OVERVIEW } \\
\text { OF ACTIVITIES }\end{array}$ & Activities of the groups are seen by all students & FACEBOOK Platform Study Groups \\
\hline $\begin{array}{l}\text { ASSESSMENT OF } \\
\text { PERFORMANCES }\end{array}$ & Watch the videos of classmates and their reflections & Recording interviews of participants \\
\hline $\begin{array}{c}\text { GROUP } \\
\text { ASSESSMENT }\end{array}$ & Learning how to judge the participations & Use of FACEBOOK Platform Study Groups \\
\hline $\begin{array}{l}\text { ASSESSMENT BY } \\
\text { STUDENTS - } 360^{\circ}\end{array}$ & Everyone evaluate everyone & $\begin{array}{c}\text { Assessment through posts on the FACEBOOK } \\
\text { environment }\end{array}$ \\
\hline $\begin{array}{l}\text { PUBLICATION ON THE } \\
\text { SOCIAL ENVIROMENT }\end{array}$ & $\begin{array}{l}\text { Collective and individual production of school } \\
\text { subjects }\end{array}$ & Publication in YOUTUBE web pages \\
\hline $\begin{array}{l}\text { CONSTRUCTION OF } \\
\text { THE E-SOCIAL } \\
\end{array}$ & $\begin{array}{l}\text { Construction of the students' image in social } \\
\text { networks }\end{array}$ & Social networking in education \\
\hline
\end{tabular}

SOURCE: Author.

This table shows the indicators used to observe the characteristics of the educational model proposed in the research and verify the deterritorialization of the TEACHER and STUDENT fields, seeking to enter new existing aspects and characteristics through assignments to the actors of education.

\section{Research Indicators}

The analysis of the experiences that occurred during the study were grouped into the characteristics described in the table above, and then exposed to the observations of the researcher:

SCHOOL RESEARCHES - This indicator noted the scientific and school experiences in the classroom as a methodological, pedagogical and didactic preference in the classroom. For this, the research suggested researches on search engine sites on the Internet for the topics proposed for student groups of five-four participants. For this research it was suggested that the information was prepared and worked to be transformed into audios and videos recorded by the students themselves.

GROUP ACTIVITIES - This indicator was chosen to study how students would perform the tasks having a virtual communication, interaction and collaboration environment, such as FACEBOOK. The main request was that students would also use the FACEBOOK chat environment in addition to e-mail to ask questions and talk through the existing audio and video chatting feature.

AUDIO AND VIDEO MEDIA - For this indicator the students were asked to record audio and video for the proposed activity. It was requested for a research to be conducted and for the information to be worked in the format of a script and recorded in videos. Students and teachers were trained to use the FORMAT FACTORY software, which allows you to change the file type to the types accepted by MOVIE MAKER, to be used for editing and placement of credits.

SUPERVISED STAGES - For this indicator, students were asked to publish individual videos for each stage of the research and published in YOUTUBE and the video link to be placed on the FACEBOOK environment, in study group built for this purpose. In order for the research to be guided by teachers during the process of information survey and reflections, a working methodology was adopted in which students should publish every step they took in the research. The result of these steps should be published on YOUTUBE in the form of testimonials and interviews.

CONSTRUCTION OF DOCUMENTS - In this indicator students should build a scientific technical paper type document with the information researched. The particulars of the documents produced by the students during the gathering of information were transformed into scientific texts or even scientific papers with the possibility of publication. Technical notebooks were created so they could be consulted by subsequent classes and in the school's science fairs.

REFLECTIONS AND ROLES ASSUMED -In this indicator students were asked to reflect on the subjects researched and for all members of each group to have effective participation in producing the final video. The challenge was for the students to be able to read the information researched and build a reflection on the subject, with the purpose of recording videos.

INDIVIDUAL PARTICIPATIONS - This indicator required each group member to have a significant role both in the search for information as well as in the reflection that should be performed on camera. This way we would know exactly what each one had researched, 
reflected and produced to make up the whole of the research.

OVERVIEW OF ACTIVITIES - Students were asked to perform recordings of the discussions between them on the subjects researched as well as talk about the interviews conducted with teachers from other areas, thus providing the interdisciplinary required with other areas of knowledge.

ASSESSMENT OF PERFORMANCES - With the purpose of recording the videos, students should watch the participations of all work carried out. All videos were published in the students' YOUTUBE channels and then posted in closed groups for research on the FACEBOOK environment. The assessments that students made of themselves and others was felt in the group discussions that took place in the classroom. Some videos were redone because of these observations

GROUP ASSESSMENT - The groups of students surveyed were asked to conduct an assessment of each member of the group. For this, they would have to watch the videos of classmates and reflect on the participation of each. In this regard, students would be studying the participation of classmates and building the idea of thorough research.

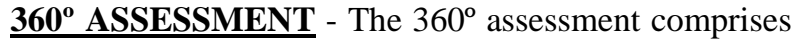
the student's activity to assess all classmates in the aspects of production of information, video scripts and effective participation in the images. All participants should examine the participations and learn from the reflections of classmates.

PUBLICATION IN SOCIAL MEDIA - Each participant should create a YouTube channel to publish their participation in the activities. In addition, they should also place links of the videos on the FACEBOOK Study Group Environment.

E-SOCIAL CONSTRUCTION - Students were invited to create profiles on the social network to learn how to live with the use of image in an increasingly mediatic world. Generations $\mathrm{X}$ and $\mathrm{Y}$, are known by the use of mobile devices and the ease of use of audio and video in society.

\subsection{Research Results and Assessment}

According to results obtained through the process of process assessment collection instruments (questionnaires and interviews), the indicators showed significant changes in the patterns of the traditional methodology of teaching and learning. In all, 398 questionnaires were collected from students and 9 interviews with teachers, divided into the groups surveyed and analyzed.

The results obtained in the study showed significant figures as to the improvement in learning. In the researched aspects, evidence was found that the adopted methodology can represent significant advances in improving teaching practices. The observed aspects and differences demonstrated in the two determined models are presented below: traditional education teaching $\mathrm{x}$ education proposed with the use of the methodology presented.

For the assessment of the learning of the participants surveyed, the traditional assessment system was used (tests). Two collection instruments were applied: a questionnaire on the impressions of the educational model that was being applied and a test worth a grade for the final composition of the assessment of the subject by the teacher. Students knew that the proposed activities would have a test at the end of the activity and that this would go to the composition of the final grade at the end of the reporting period.

According to the teachers' data of the subjects participating in the study, students' grades in classes prior to the research presented lower results on the same subjects addressed in an interdisciplinary manner and using audio and video technologies. The graphical indicators of the results achieved with the application of the methodology in the research and graphics of classes prior to the research are presented below:

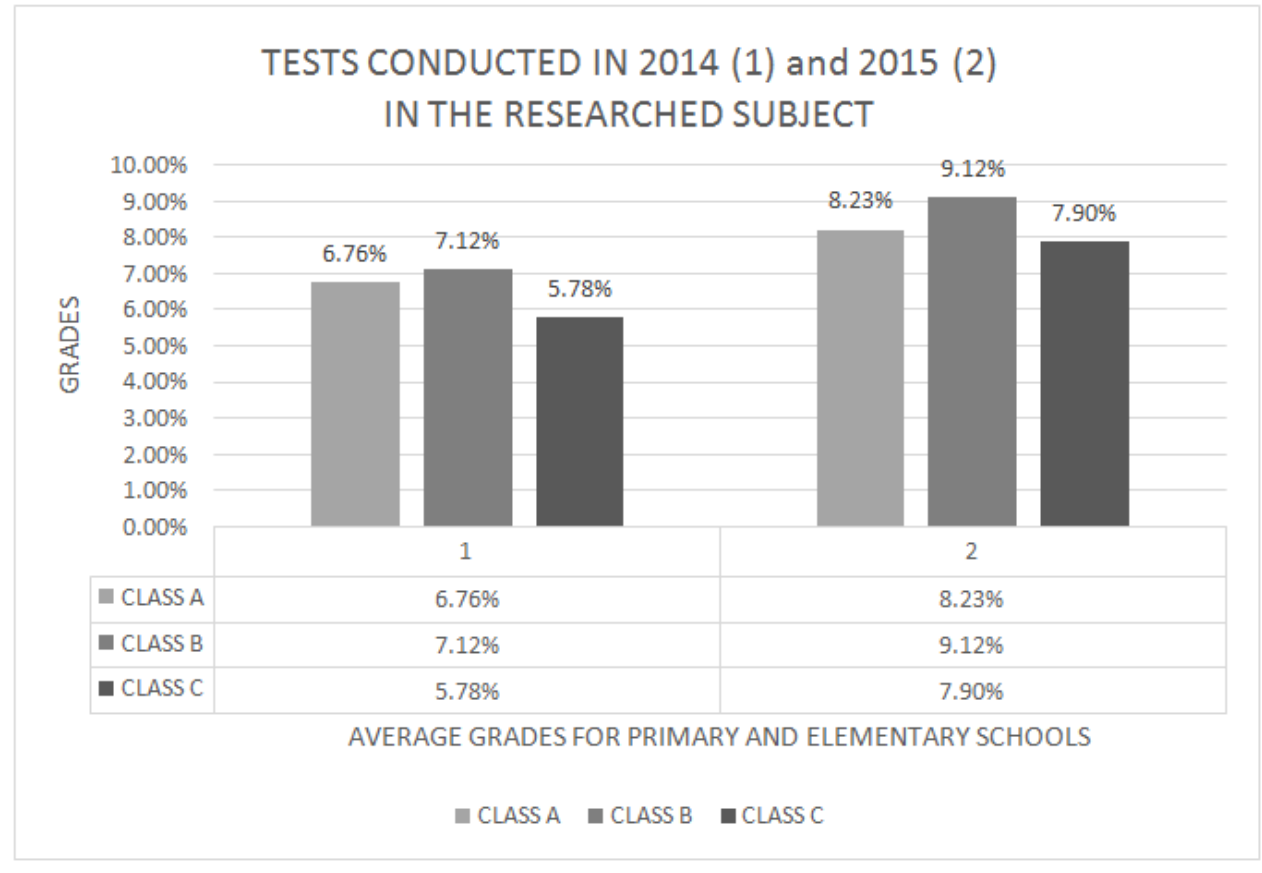

Graph 1. RESULTS ACHIEVED IN TESTS (in English) (SOURCE: Author)

Notes: These figures refer to the average grades achieved in primary and secondary school classes. 
Only the content related to the research was considered in the test, that is, the purpose is to investigate the effectiveness and efficiency of the teaching methodology using interdisciplinary teaching practices, social networking in education and audio and video media in the production of school content.

\subsection{Surveying Information}

In order to survey the information, information gathering instruments were used through questionnaires and interviews with the respondents. Five areas were used for the research: interdisciplinary aspect, communicative aspect, technological aspect, behavioral aspect and methodological aspect.

Interdisciplinary aspect: two or more teachers in the classroom were presented to the groups analyzed in three experiences of interdisciplinary lessons, and according to the testimonies of students and teachers, the classes became stages of epistemological debates on the subjects approached, showing those who were present that the dialogic discussions provided by these meetings, brought the subjects together, decreasing the gaps between them, even addressing the frontiers of science. The result, as noted in the information gathering instruments, "brought more movement and reflection providing spaces for discussion, questions and answers", according to secondary school student (A) of one of the groups surveyed.

$2 \%$ of teachers had some concept of the interdisciplinary methodology of teaching and learning. 78\% said they had a misconception about interdisciplinarity, as they performed interdisciplinary projects without active communication in the classroom, with the students, going against the main premise of interdisciplinarity that is the intersection of knowledge in action and reflection [12].

However, the $22 \%$ who knew the conceptual and correct use of interdisciplinarity did not practice it because schools are not physically prepared for this educational model, given that most teachers work in different schools and may not be in classrooms with other teachers, since they would have to be in other schools.

Communicational Aspect: use of social networks - In traditional teaching, most of the surveyed institutions do not have a suitable communication tool for students, in and out of school. 92\% of teachers claimed to use Moodle for logistical and strategic support, that is, to relate with students regarding the availability of teaching materials such as text, activities, exercises and even tests, and that the communication resources and asynchronous activities are not well regarded by students, becoming non-effective and counterproductive.

As a result of the research, the educational use of social networks as a communication environment, interaction and collaboration was very efficient under different aspects: increased the speed in communications (88\%), is an environment where students want to be constantly (92\%), posts were considered sources of study (78\%), social networking provided spaces for relationships that were non-existent in person in the classroom (81\%), presentation of posts with photos, pictures, audio and video of activities that help improve understanding of school subjects (94\%) and group work (77\%).

Technological Aspect: The use of Audio and Video media - In traditional teaching, in most of the surveyed institutions, general videos were used in the classroom. But these are ready to use videos, created by educational institutions or specialized companies. The configuration proposed by the methodology was that for students themselves to develop research on disciplinary themes, enter into in small groups of 4-5 students, carry out the research suggested by teachers and record videos of reflections made on the subject.

The result was that $94 \%$ of teachers said that the students themselves prefer to build the disciplinary content, they just didn't know how. 84\% of students were more motivated to carry out group work with the use of social networks and audio and video media. 97\% would like to conduct interviews with other teachers in the school and beyond.

Behavioral Aspect: Personal exposure - In traditional teaching, the majority of actors surveyed (teachers and students) claimed that students generally do not have the culture of physical exposure in the classroom, that is, are ashamed to report research and educational activities personally and orally. This is due to the fact of traditional teaching methodology being lecture-oriented, leaving the teacher as the protagonist in a position to expose the contents and the student in a position of just receiving information for most of the time, without spaces produced in class for reflection and exchange of views on the information covered. With the methodology proposed in the research, we could see that students felt more inclined and motivated to research and to produce information, in addition to the motivation of appearing in the videos.

According to the students' testimony, the exposure in the videos allowed them to be self-critic on their participations, resulting in a greater acuity in the following presentations, gradually improving their quality. The improvement of the performances and the quality of content is quite clear. The reflection on the information surveyed also brought considerable improvement, if we analyze the assessments (tests) done at the end of the research.

Methodological Aspect: Change in pedagogical practices - With the research, changes in the behavior of teachers can be observed regarding training and qualification to the suggested interdisciplinary methodologies, group activities and production of audio and video media in the production of school content by the student.

The interdisciplinary methodology has shown that two or more teachers discussing in the classroom with students on the topics covered on the syllabus of each subject enabled a greater understanding of educational issues, improving the dynamics in the classroom, allowing the use of different media such as cell phones, tablets, computers, social networking, audio and video production, and making classes less lecture-oriented, placing teachers as facilitators in the search for information, and placing students in a group of protagonists in the search, reflection and learning of the phenomena studied.

\section{Conclusions}

The interdisciplinary experiences occurred during this study showed that it takes further investigations in the direction of improving educational techniques and methodologies for the wider use of the interdisciplinary 
spectrum of working with education. Experiences acquired allow to reflect on pedagogical practices, didactics and teaching techniques used in the classroom, not only by the cumulative aspect, but also by the fact that they return recursively, providing mechanisms for the systematization of new interventions for its actors in order to verify other potential indicators of improvement of interdisciplinary teaching practices, creating a permanent vocation of teachers to examine from behavior to the logic of production, interaction and collaboration of new practices.

The research has shown, by the results obtained, that students from generation $\mathrm{X}$ and $\mathrm{Y}$, endowed with ubiquitous learning, regarding mobile and electronic equipment, are ready to apply this knowledge in schools, being of great value to the educational system, contributing to the effectiveness and efficiency of the teaching and learning binomial. But on the other hand, they require a new deterritorialization in education, assuming that new aspects and characteristics of the teacher and student roles need to be incorporated into the universe of classroom relationships, so that assumptions may be considered on the proposal of delocalization and spatialization of the classroom.

The practices adopted in this expanded universe of physical and virtual environments, have made it clear with this research that training and qualification of all actors involved is needed, because if teachers recognize that they need assistance to deal with technological, modern and innovative artifacts, they also need methodologies that improve technological insertions to the educational system. If interdisciplinarity allows this path to evolve in the educational environment, it is necessary to understand how this phenomenon operates on different levels of relationships, behaviors, interactions and needs of each of the subjects involved.

The results obtained in this study allow progress to educational models that use technology not only to teach school subjects, but also for their direct use in learning, providing opportunities for communication, interaction and collaboration among students, socializing information, creating more spaces for reflection and understanding of phenomena, understanding that the resulting information of disciplinary and epistemic form can be transformed into knowledge, interpreted in a more transdisciplinary, holistic and comprehensive view.

Indeed, the assumptions used in traditional teaching shall continue to exert pressure to sustain this new horizon that is unfolding, where reading, writing, logic, mathematics and reflection will remain important multisemiotic literacies, and what is sought is to improve how these literacies can be exercised in all its potential to achieve quality education and learning that is meaningful to students.

In this study we sought to investigate some aspects observed in classroom behavior and cultural heritage exerted by traditional methodologies, analyzing some aspects and characteristics of the need of deterritorialization in education. However, we need other studies and indicators that can bring systemic structures and needs as to the coexistence of the different analyzed multisemiotic literacies (reading, writing, pictures, photos, audio and video), under the light of science of observation and scientific research to further improve the five areas covered by the survey (interdisciplinary, communicational, technological, behavioral and methodological) as key elements in the training and qualification of teachers.

\section{References}

[1] AGNEW, J. Place and politics. The Geographical Mediation of State and Society. Boston: Allen Unwin. 1987

[2] BARABÁSI, A. et al. Evolution of the Social Network of Scientific Collaborations. Physica A, 311. 2002.

[3] BARABÁSI, A. et al. Linked. How Everything is Connected to Everything else and What it means for Business, Science and Everyday Life. Cambridge: Plume, 2003.

[4] BÉVORT, E. \& BELLONI, M.L. Mídia-educação: conceitos, história e perspectivas. Educação e Sociedade, Campinas, vol. 30, n. 109, p. 1081-1102, set/dez. 2009. Available at: http://www.cedes.unicamp.br.

[5] BOURDIEU, P. Classificação, desclassificação, reclassificação. NOGUEIRA M.A. \& CATANI, A. (org.) Escritos de Educação. 3. ed. Petrópolis: Vozes, 1998.

[6] CASTELLS, Manuel. A sociedade em rede - A era da informação: economia, sociedade e cultura - Vol.1. São Paulo: Paz e Terra, 2003.

[7] CRESSWELL, T. Place: A Short Introduction. Oxford, UK: Wiley.. 2004

[8] DELEUZE, G.. L'Ile Deserte et d'autres textes: textes et entretiens 1953-1974. Paris: Ed. de Minuit. 2002

[9] DELEUZE, G. e GUATTARI, F. s/d. [ed. original: 1972] O AntiÉdipo: capitalismo e esquizofrenia. Lisboa: Assírio \& Alvim. 1992. O que é a Filosofia? Rio de Janeiro: Ed. 34. 1995a. Mil Platôs: capitalismo e esquizofrenia. Vol.1. Rio de Janeiro: Ed. 34. $1995 b$.

[10] DIZARD, W. A nova mídia - a comunicação de massa na era da informação. Trad. Edmond Jorge. Jorge Zahar Editor, RJ, 1998.

[11] FANTIN, M. A Mídia na Formação Escolar de Crianças e Jovens. Anais do XXXI Congresso Brasileiro de Ciências da Comunicação, INTERCOM, Natal, 2008.

[12] FAZENDA, I. (Org.). Interdisciplinaridade na educação brasileira: 20 anos. São Paulo: Criarp, 2006.

[13] GUARESCHI, P.; BIZ, O. Mídia e Democracia. Porto Alegre: Evangraf, 2005.

[14] GUATTARI, E ROLNIK, S. Micropolítica: cartografias do desejo. Petrópolis: Vozes. 1996.

[15] IANNI, O. A sociedade global. Rio de Janeiro, Civilização Brasileira, 1992.

[16] IANNI, O. A era do globalismo. Rio de Janeiro, Civilização Brasileira, 1996.

[17] IANNI, O. "Sociedade global, história e transculturação". In: TAVARES DOS SANTOS, J.V. Op. cit., 1999.

[18] LIPOVETTSKY, G. O império do efêmero: a moda e seu destino nas sociedades modernas. Tradução Maria Lúcia Machado. São Paulo: Companhia das Letras. 1989.

[19] MEDITSCH, Eduardo. A compreensão da mensagem no radiojornalismo: uma abordagem cognitiva. In: XXVI Congresso Brasileiro dos Pesquisadores da Comunicação, Belo Horizonte, Intercom, 2003.

[20] MEDITSCH, Eduardo. O Rádio na era da informação: teoria e técnica do novo radiojornalismo. Florianópolis: EDUFSC e Insular, 2001.

[21] MITCHELL, William. Diálogo com William J. Mitchell. Lugares, arquiteturas e memórias. In Casalegno Federico. Memória cotidiana. Comunidades e comunicação na era das redes. Porto Alegre: Sulina, 2006.

[22] MORIN, E. A cabeça bem-feita: repensar a reforma, reformar o pensamento. 15. ed. Rio de Janeiro: Bertrand do Brasil, 2008

[23] SANTAELLA, L. Produção de linguagem e ideologia. São Paulo : Cortez, 1996.

[24] SANTAELLA, L. O que é semiótica. São Paulo : Brasiliense, 1983.

[25] SILVERSTONE, R. Por que estudar a Mídia? São Paulo: Edições Loyola, 2005.

[26] TERUYA, T. Sobre mídia, educação e Estudos Culturais. In. MACIEL, Lizete Shizue Bomura; MORI, Nerli Nonato Ribeiro (Org.) Pesquisa em Educação: Múltiplos Olhares. Maringá: Eduem, 2009. P. 151-165. 